nce pests and diseases become established, their interactions with crops, landscapes or animals are in a continuous state of flux, depending on environmental conditions and changes in pest control practices. Their long-term management is never static; it relies on a combination of techniques and strategies. The articles in this section take the long view and present how UC scientists tackle the evolution of a pest problem - herbicide resistance - and how the UC Statewide IPM program has managed pests while minimizing environmental risks for 35 years.

\title{
Herbicide-resistant weeds challenge some signature cropping systems
}

by Bradley D. Hanson, Steven Wright, Lynn M. Sosnoskie, Albert J. Fischer, Marie Jasieniuk, John A. Roncoroni, Kurt J. Hembree, Steve Orloff, Anil Shrestha and Kassim Al-Khatib

Invasive and endemic weeds pose recurring challenges for California land managers. The evolution of herbicide resistance in several species has imposed new challenges in some cropping systems, and these issues are being addressed by UC Cooperative Extension farm advisors, specialists and faculty. There are currently 24 unique herbicide-resistant weed biotypes in the state, dominated by grasses and sedges in flooded rice systems and, more recently, glyphosate-resistant broadleaf and grass weeds in tree and vine systems, roadsides and glyphosate-tolerant field crops. Weed scientists address these complex issues using approaches ranging from basic physiology and genetics research to applied research and extension efforts in grower fields throughout the state. Although solutions to herbicide resistance are not simple and are affected by many biological, economic, regulatory and social factors, California stakeholders need information, training and solutions to address new weed management problems as they arise. Coordinated efforts conducted under the Endemic and Invasive Pests and Disease Strategic Initiative directly address weed management challenges in California's agricultural industries.

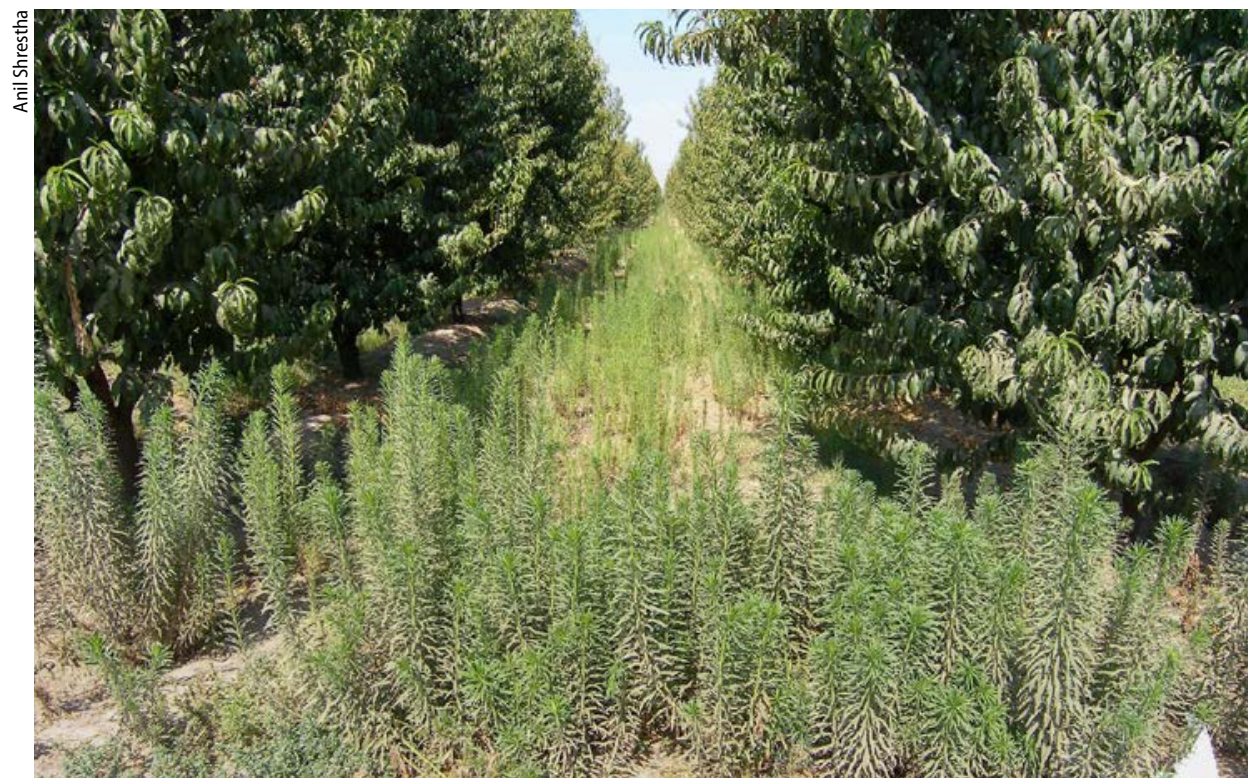

A stone fruit orchard in Fresno County is dominated by glyphosate-resistant horseweed. Reliance on one method of weed control imposes selection pressure, which can lead to population shifts to tolerant species or selection of resistant biotypes.
$\mathrm{E}$ ndemic and invasive weeds are important management concerns in California due to their direct and indirect costs to agriculture, the environment and society. Pimentel et al. (2005) estimated that weeds cost U.S. crop producers and pasture managers over $\$ 30$ billion in control-related expenses and reduced productivity. Although specific data are not available for California's portion of these losses, weed management costs for the state's 40 million acres of crop and grazing lands, as well as the remaining 60 million acres of land area, amount, undoubtedly, to several billion dollars annually. In addition to the direct cost of weed control and lost agricultural productivity, weeds also affect ecosystem quality and function, reduce recreational access and degrade aesthetics in natural areas, change wildland fire regimes and severity, and impede water flow through rivers and canals, among other negative impacts.

Although crop weeds are seldom considered as being "invasive" in the traditional sense, novel biotypes can develop, spread and subsequently occupy a greater proportion of crop acreage than might normally be expected. For example, when a weed population evolves resistance to an herbicide or any other control measure, a "routine" pest can become a new and serious problem. The first case of an herbicide-resistant weed in California was reported in 1981 by UC scientists (Holt et al. 1981); in recent years, additional species have evolved resistance to various herbicide chemistries (table

Online: http://californiaagriculture.ucanr.edu/ landingpage.cfm?article $=$ ca.v068n04p142\&fulltext=yes doi: 10.3733/ca.v068n04p142 
1) used in some of California's signature cropping systems, including flooded rice, orchards and vineyards as well as nearby noncrop areas.

\section{How do weeds become resistant to herbicides?}

Environmental factors and production practices influence species composition at any location, a phenomenon known as selection pressure. Under constant conditions, the weed community will become dominated by species that thrive under those conditions. If this steady state is upset by a change in management practices, a weed shift may occur, resulting in a community dominated by different species adapted to the new conditions (Hanson et al. 2013). This weed shift can be caused by agronomic and horticultural practices (tillage, fertility, irrigation, etc.) or by the use of herbicides, which are very strong selective agents. Some species will be less susceptible (more tolerant) than others to any management practice, and repeated use of the same control strategy can shift weed populations to become dominated by naturally tolerant species (fig. 1A).

Herbicide resistance, on the other hand, implies that a genetic change has caused a formerly susceptible population of a species to become resistant to an herbicide. Herbicide resistance arises from the process of adaptive evolution, whereby mutations change the physiology of plants in such a way that the herbicide is less effective. Under the continued selection pressure exerted by the herbicide(s), resistant plants with the new genotype are not controlled, and their offspring build up in the population (fig. 1B). Depending on the initial frequency and genetic basis of resistance, the regularity and rate of herbicide applications, and the reproductive system of the weed, it may take from a few to many generations for resistance to become

TABLE 1. Important herbicide modes of action

\begin{tabular}{|c|c|c|c|}
\hline Mode of action & WSSA group & Target site and effects & Herbicide examples \\
\hline ACCase inhibitors & 1 & $\begin{array}{l}\text { Several important classes include aryloxyfenoxypropionates, } \\
\text { cyclohexanediones and phenylpyrazolin. These herbicides inhibit the } \\
\text { enzyme acetyl coenzyme A carboxylase (ACCase), which leads to the } \\
\text { disruption of lipid synthesis at the growing point of susceptible grasses. }\end{array}$ & $\begin{array}{l}\text { Clethodim, cyhalofop, diclofop, } \\
\text { fluazifop, pinoxaden, sethoxydim, many } \\
\text { others }\end{array}$ \\
\hline ALS inhibitors & 2 & $\begin{array}{l}\text { Several herbicide classes including the imidazolinones and sulfonylureas } \\
\text { and others inhibit the enzyme acetolactate synthase (ALS), which } \\
\text { disrupts synthesis of branched-chain amino acids. }\end{array}$ & $\begin{array}{l}\text { Bensulfuron, chlorsulfuron, } \\
\text { halosulfuron, imazamox, imazethapyr, } \\
\text { metsulfuron, rimsulfuron, } \\
\text { sulfometuron, many others }\end{array}$ \\
\hline $\begin{array}{l}\text { Carotenoid synthesis } \\
\text { inhibitors }\end{array}$ & $11,12,13,27$ & $\begin{array}{l}\text { Several unrelated chemical classes block enzymes important in the } \\
\text { synthesis of carotenoids and/or chlorophyll. Because carotenoids protect } \\
\text { plants from excess oxidative energy, lack of carotenoids usually results in } \\
\text { membrane and protein damage from free radicals. }\end{array}$ & $\begin{array}{l}\text { Amitrole, clomazone, fluridone, } \\
\text { mesotrione, norflurazon, topramezone, } \\
\text { others }\end{array}$ \\
\hline Cellulose inhibitors & $20,21,27$ & Several chemical classes inhibit aspects of cell wall (cellulose) synthesis. & $\begin{array}{l}\text { Dichlobenil, indaziflam, isoxaben, } \\
\text { quinclorac }\end{array}$ \\
\hline EPSPS inhibitors & 9 & $\begin{array}{l}\text { The glycine herbicides inhibit the enzyme 5-enolypyruvylshikimate-3- } \\
\text { phosphate synthetase (EPSPS), which is important in the synthesis of } \\
\text { aromatic amino acids. }\end{array}$ & Glyphosate \\
\hline $\begin{array}{l}\text { Fatty acid and lipid synthesis } \\
\text { inhibitors }\end{array}$ & $8,16,26$ & $\begin{array}{l}\text { Several chemical classes, including the thiocarbamates, inhibit processes } \\
\text { important in the synthesis of fatty acid and lipids, impacting production } \\
\text { of membranes, proteins, hormones and other cellular components. }\end{array}$ & $\begin{array}{l}\text { Bensulide, butylate, EPTC, molinate, } \\
\text { triallate, vernolate, others }\end{array}$ \\
\hline $\begin{array}{l}\text { Glutamine synthetase } \\
\text { inhibitors }\end{array}$ & 10 & $\begin{array}{l}\text { Phosphonic acid herbicides inhibit the enzyme glutamine synthetase. } \\
\text { Blocking of this process leads to buildup of ammonia in the plant and } \\
\text { also inhibits PSII and PSI. }\end{array}$ & Glufosinate \\
\hline Mitosis inhibitors & $3,15,23$ & $\begin{array}{l}\text { Several different chemical families affect various processes important in } \\
\text { cell division. The most widely used include chloroacetemides (Group 3) } \\
\text { and dinitroaniline (Group 15) herbicides. }\end{array}$ & $\begin{array}{l}\text { Alachlor, dimethenamid, metolachlor, } \\
\text { oryzalin, pendimethalin, pronamide, } \\
\text { trifluralin, many others }\end{array}$ \\
\hline Photosystem I inhibitors (PSI) & 22 & $\begin{array}{l}\text { PSI inhibitors divert electrons during photosynthesis and create free } \\
\text { radicals that quickly degrade cell membranes and lead to cell and tissue } \\
\text { desiccation. }\end{array}$ & Paraquat, diquat \\
\hline Photosystem II inhibitors (PSII) & $5,6,7$ & $\begin{array}{l}\text { Herbicide classes including the triazines, uracils, amides and several } \\
\text { others disrupt photosynthesis by blocking electron transport in PSII. } \\
\text { Plant death usually occurs from protein and lipid oxidation caused by } \\
\text { free radicals. }\end{array}$ & $\begin{array}{l}\text { Atrazine, bromacil, diuron, hexazinone, } \\
\text { linuron, propanil, simazine, } \\
\text { tebuthiuron, others }\end{array}$ \\
\hline Synthetic auxins & 4 & $\begin{array}{l}\text { Benzoic acids, phenoxycarboxylic acids, pyrachlor and pyridine } \\
\text { carboxylic acids mimic endogenous auxins. At high concentrations, } \\
\text { these growth regulator herbicides lead to uncontrolled cell division and } \\
\text { growth and can stimulate ethylene production. }\end{array}$ & $\begin{array}{l}\text { 2,4-D, aminocyclopyrachlor, } \\
\text { aminopyralid, clopyralid, dicamba, } \\
\text { MCPA, quinclorac, triclopyr, others }\end{array}$ \\
\hline
\end{tabular}

For a more complete listing and description of herbicide modes of action, refer to the Weed Science Society of America (WSSA) website at http://wssa.net/wp-content/uploads/ WSSA-Mechanism-of-Action.pdf. 
apparent (Jasieniuk et al. 1996; Maxwell et al. 1990).

\section{Current status of herbicide resistance}

The strongest selection pressure for herbicide-resistant weeds tends to be in modern, high-intensity agricultural cropping systems due to a high reliance on herbicides. According to the International Survey of Herbicide Resistant Weeds (weedscience.org), since the first confirmed report of a resistant biotype in
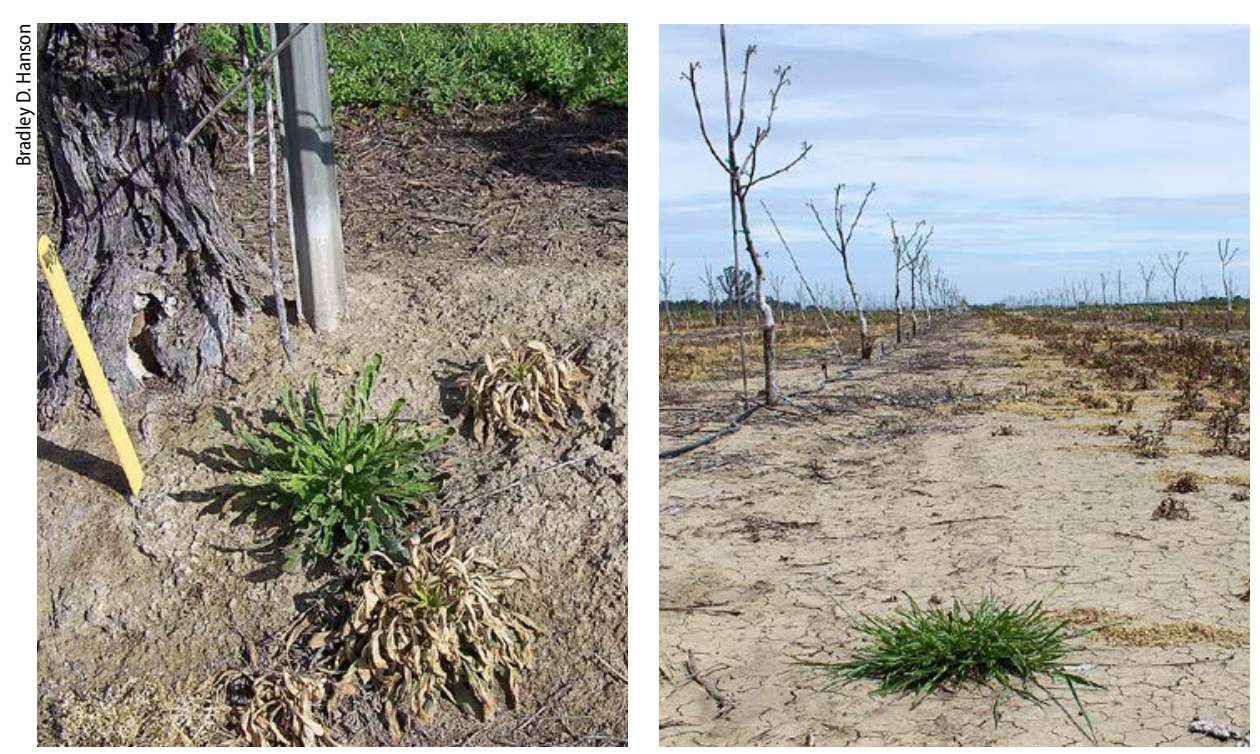

Glyphosate-resistant horseweed in a raisin vineyard near Parlier, left, and glyphosate-resistant ryegrass in a walnut orchard near Davis.
1957, herbicide-resistant weed biotypes have been reported in at least 60 countries and include more than 400 unique species-herbicide group combinations (fig. 2A). The United States has more herbicide-resistant biotypes (162) than any other country (fig. 2B), and California accounts for 21 of these (fig. 2C, table 2). Worldwide, resistance to acetolactate synthase (ALS)-inhibiting herbicides and photosystem II (PSII)-inhibiting herbicides (Groups 5, 6 and 7) are the most commonly occurring among weedy species. However, in recent years, glyphosate (glycine herbicide) resistance and multiple resistances (resistance to two or more herbicides with dissimilar modes of action) have also emerged as major problems in some cropping systems. Interestingly, while herbicide resistance in the United States as a whole is primarily found in broadleaf weeds, California has more herbicide-resistant grasses or sedges (15) than broadleaf species (6) (table 2).

Due to the extensive use of preplant and in-season tillage in some agronomic crops in California, along with the use of pre- and postemergence herbicides, herbicide resistance is not as widespread as it is in other parts of the country where no-till and minimum-till systems have been widely adopted. Reduced tillage systems are heavily reliant on a few herbicide modes of action (e.g., glyphosate) and have correspondingly larger problems with herbicide resistance (Culpepper 2006).

In contrast to the rest of the United States, where herbicide resistance problems are centered on agronomic crops, the greatest problems with herbicideresistant weeds in California are in orchards, vineyards, flooded rice, roadsides and irrigation canal banks. Herbicideresistant weeds have become especially
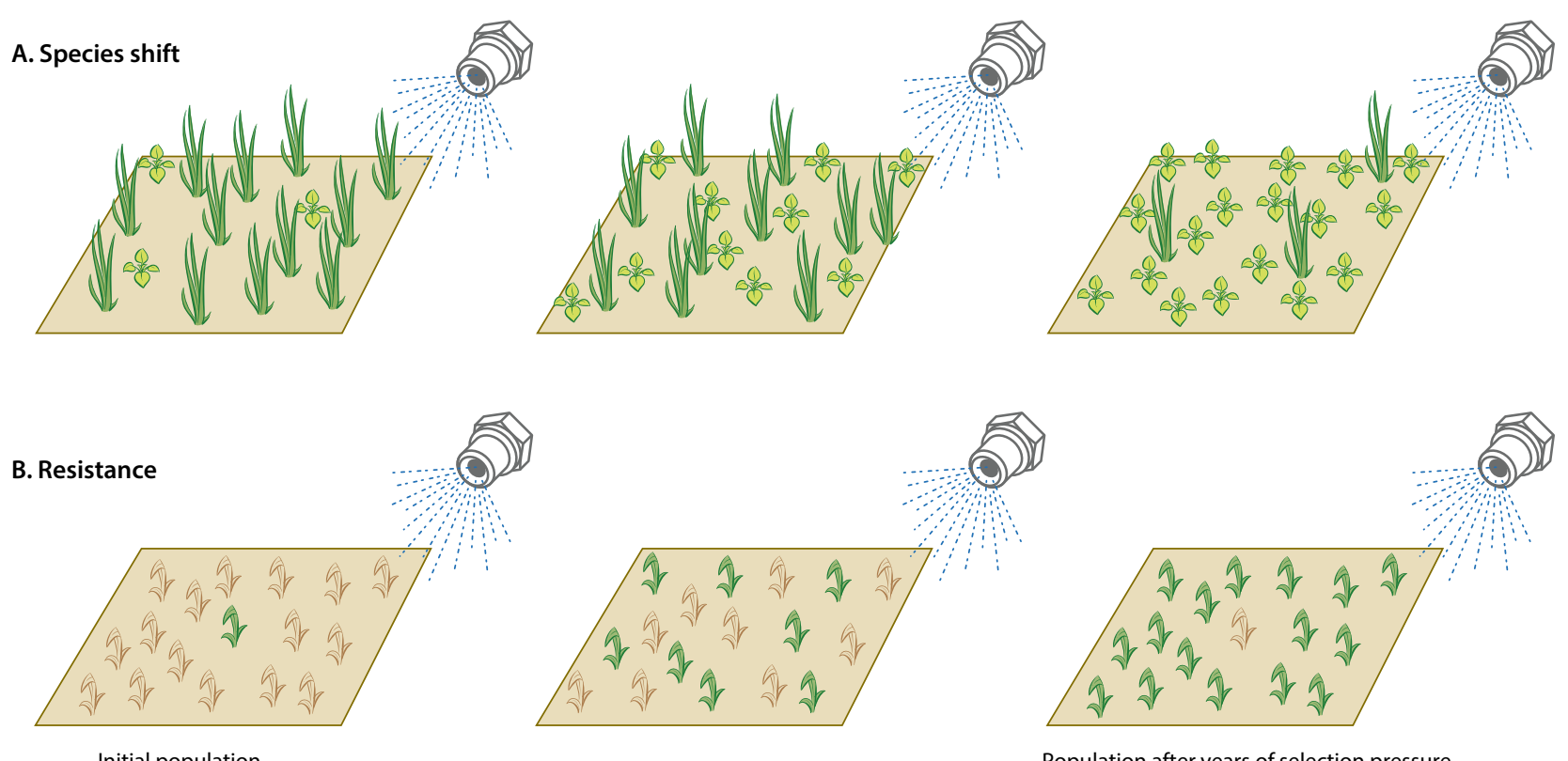

Initial population

Population after years of selection pressure

Fig. 1. Herbicides impose selection pressure and can lead to weed species shifts, resulting in populations dominated by more-tolerant species (A). Occasionally, an individual weed has a mutation that confers resistance to an herbicide or group of herbicides, and this individual survives and reproduces despite being treated with herbicide (B). In both cases, after several generations and repeated selection with the same or similar herbicides, the tolerant species or resistant biotype can become dominant in the population. (Modified from Orloff et al. 2009 with permission.) 
challenging problems in California's signature cropping systems, which are characterized by little or no crop rotation due to soil limitations (rice) or long cropping cycles (orchards and vineyards) and relatively few opportunities for mechanical weed control. Although large by specialty crop standards, the approximately 3 million acres devoted to orchard, vineyard and rice production in California is a small market for herbicide manufacturers; thus, herbicide options are somewhat limited. Combined, these factors have led to a high degree of selection pressure for herbicide-resistant weed biotypes as well as weed population shifts to naturally tolerant species (Hanson et al. 2013; Prather et al. 2000).

\section{TABLE 2. Confirmed cases of herbicide-resistant weeds in California}

\begin{tabular}{|c|c|c|c|}
\hline Scientific name & Common name & Year & Mode of action* \\
\hline Senecio vulgaris & Common groundsel & 1981 & PSII inhibitor \\
\hline Lolium perenne & Perennial ryegrass & 1989 & ALS inhibitor \\
\hline Cyperus difformis & $\begin{array}{l}\text { Smallflower umbrella } \\
\text { sedge }\end{array}$ & 1993 & ALS inhibitor \\
\hline $\begin{array}{l}\text { Sagittaria } \\
\text { montevidensis }\end{array}$ & California arrowhead & 1993 & ALS inhibitor \\
\hline Salsola tragus & Russian-thistle & 1994 & ALS inhibitor \\
\hline Avena fatua & Wild oat & 1996 & $\begin{array}{c}\text { Pyrazolium } \\
\text { (difenzoquat) }\end{array}$ \\
\hline Ammannia auriculata & Eared redstem & 1997 & ALS inhibitor \\
\hline $\begin{array}{l}\text { Schoenoplectus } \\
\text { mucronatus }\end{array}$ & Ricefield bulrush & 1997 & ALS inhibitor \\
\hline $\begin{array}{l}\text { Echinochloa } \\
\text { phyllopogon }\end{array}$ & Late watergrass & 1998 & Thiocarbamate \\
\hline $\begin{array}{l}\text { Echinochloa } \\
\text { phyllopogon }\end{array}$ & Late watergrass & 1998 & $\begin{array}{l}\text { Multiple (ACCase } \\
\text { inhibitor, ALS inhibitor, } \\
\text { thiocarbamate and } \\
\text { clomazone) }\end{array}$ \\
\hline Lolium rigidum & Rigid ryegrass & 1998 & Glycine \\
\hline Ammannia coccinea & Redstem & 2000 & ALS inhibitor \\
\hline Echinochloa crus-galli & Barnyardgrass & 2000 & $\begin{array}{c}\text { Multiple (ACCase } \\
\text { inhibitor and } \\
\text { thiocarbamate) }\end{array}$ \\
\hline $\begin{array}{l}\text { Echinochloa } \\
\text { phyllopogon }\end{array}$ & Late watergrass & 2000 & Thiocarbamate \\
\hline Echinochloa oryzoides & Early watergrass & 2000 & $\begin{array}{l}\text { Multiple (ACCase } \\
\text { inhibitor and } \\
\text { thiocarbamate) }\end{array}$ \\
\hline Phalaris minor & $\begin{array}{l}\text { Small-seeded } \\
\text { canarygrass }\end{array}$ & 2001 & ACCase inhibitor \\
\hline Digitaria ischaemum & Smooth crabgrass & 2002 & Synthetic auxin \\
\hline Conyza canadensis & Horseweed & 2005 & Glycine \\
\hline $\begin{array}{l}\text { Lolium perenne ssp. } \\
\text { multiflorum }\end{array}$ & Italian ryegrass & 2005 & Glycine \\
\hline Conyza bonariensis & Hairy fleabane & 2007 & Glycine \\
\hline Echinochloa colona & Junglerice & 2008 & Glycine \\
\hline Conyza bonariensis & Hairy fleabane & 2009 & $\begin{array}{l}\text { Multiple (glycine and } \\
\text { bipyridylium) }\end{array}$ \\
\hline Cyperus difformis & $\begin{array}{l}\text { Smallflower umbrella } \\
\text { sedge }\end{array}$ & 2013 & PSII \\
\hline Poa annua & Annual bluegrass & 2013 & Glycine \\
\hline
\end{tabular}

* PSII = photosystem II, ALS = acetolactate synthase, $\mathrm{ACCase}=$ acetyl coenzyme A carboxylase .
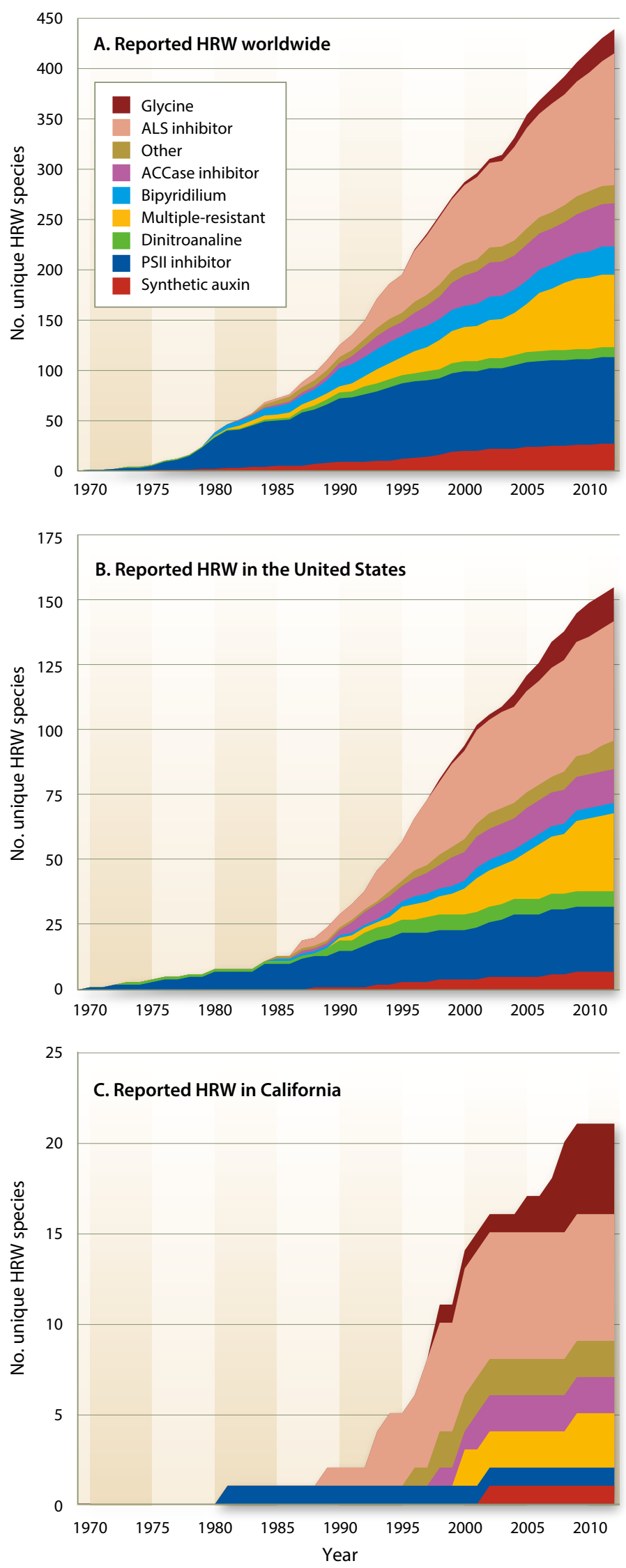

Fig. 2. Chronological increase in reports of herbicide-resistant weeds (HRW) worldwide and in the United States and California. Data compiled in August 2013 from the International Survey of Herbicide Resistant Weeds (weedscience.org). 


\section{UC weed scientists address herbicide resistance in weeds}

In order to combat complex issues such as herbicide resistance, organized collaborations between weed scientists and other agricultural researchers with a wide array of expertise are required. This includes the activities of UC Cooperative Extension farm advisors and specialists, Agricultural Experiment Station faculty, support scientists, research staff and graduate students, as well as faculty from other universities and agricultural industry representatives (for a list of UC weed scientists, visit the Weed Research and Information Center at wric.ucdavis. edu). Current herbicide-resistant weed management efforts range from applied research and extension efforts to basic plant biology and evolutionary ecology studies. Although the specifics vary, these efforts can be grouped into three general areas: (1) applied management of herbicide-resistant plants, (2) physiology and mechanisms of resistance and (3) biology, ecology and evolution of herbicide resistance.

Applied management of herbicideresistant plants. Many cases of herbicide resistance in weeds are identified after growers, land managers or pest control advisers observe weed control failures with treatments that were once effective. These weeds are generally brought to the attention of local or statewide Cooperative Extension personnel. If the herbicide application method is ruled out as the cause of poor weed control (i.e., incorrect product, rate, timing, placement, etc.), researchers often conduct field or greenhouse tests to verify and quantify the level of resistance. Plants from the suspected herbicide-resistant population are treated with the herbicide of interest at rates ranging from below normal doses to doses well above those legally allowed in the field (see photos, below). The response (i.e., plant growth or mortality) of the putative resistant population is then compared with the response of the known susceptible, or wild-type, population. Resistance is confirmed if the herbicide affects the two (or more) populations of the same species in markedly different ways with respect to plant growth and survival. In many cases, an estimate of the level of resistance also is made from these data. For example, if the susceptible population is controlled at one-half the field rate, but the resistant population survives at twice the field rate, it would be described as having a fourfold $(2 / 0.5=4)$ level of resistance.

Physiology and mechanisms of herbicide resistance. Identifying and verifying herbicide resistance and developing alternative management strategies provides short-term solutions for weed managers. Researchers often conduct further studies to determine the underlying molecular and physiological causes of resistance and to compare the biology, growth and competitive ability of herbicide-resistant species and biotypes. The mechanism(s) and fitness costs of herbicide resistance can have important ramifications on the selection, spread and competitive ability of herbicide-resistant biotypes, in addition to directly impacting their management. The goal of these efforts is to help growers and pest control advisers recognize the importance of taking a proactive approach to preventing the evolution of a resistant population, rather than a reactive approach to managing herbicide resistance after it occurs.

Target-site resistance occurs when the enzyme that is the target of the herbicide becomes less sensitive, or fully insensitive, to the herbicide, often due to a physical change in the target enzyme's structure. These physical changes can impair the ability of the herbicide (or other herbicides) to attach to a specific binding site on the enzyme, thus reducing or eliminating herbicidal activity. Target-site resistance is sometimes evaluated at the tissue level using portions of plants such as leaves, leaf disks or roots (see photos, next page). In some cases, a functioning target enzyme (e.g., ALS or acetyl coenzyme A carboxylase [ACCase]) can be extracted and its function evaluated in laboratory in vitro experiments in the presence or absence of the herbicide. Recently, overproduction or enhanced activity of the target enzyme has been shown to confer herbicide resistance in certain cases (Gaines et al. 2011).

Several mechanisms of nontarget-site resistance confer resistance to herbicides in plants without involving the target sites of the herbicides. This can result in unpredictable resistance to unrelated herbicides (Délye 2013; Délye et al 2013). Of these, the best-known cases involve resistance in which herbicide-resistant plants have an enhanced ability to metabolically degrade the herbicide to less- or
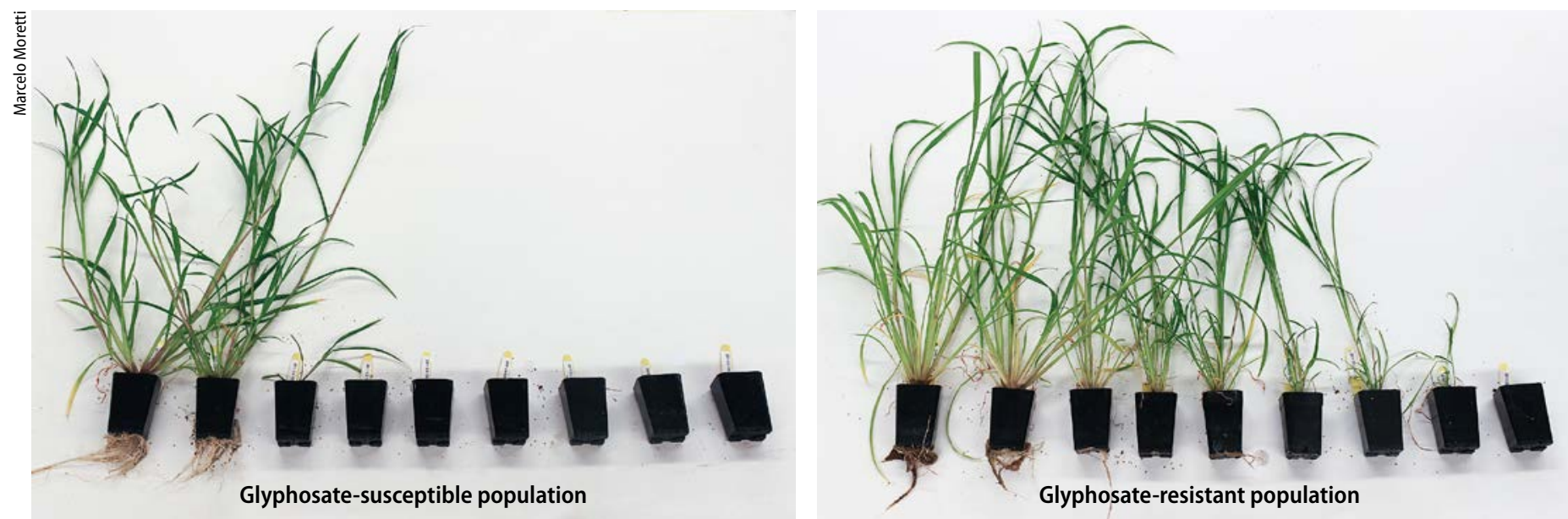

Orchard-collected junglerice plants 21 days after treatment in a greenhouse dose-response experiment. The pot at the farthest left in each photo was untreated, and the remaining plants were treated with glyphosate rates ranging from (left to right) $1 / 32 \times, 1 / 16 \times, 1 / 8 \times, 1 / 4 \times, 1 / 2 \times, 1 \times, 2 \times$ and $4 \times$ of the labeled use rate. The glyphosate-susceptible population was controlled with a $1 / 4$ use rate, while the resistant population had some survivors at the $4 \times$ rate. 
nontoxic forms. Many processes can be involved in metabolic resistance, but the most well-understood cases are due to changes in three groups of isozymes (cytochrome P450 monoxidases, glutathione transferases and glycosyltransferases) and changes in ATP-binding cassette (ABC) transporters (Yuan et al. 2007). This type of resistance is most commonly evaluated using nonherbicidal inhibitors of the various isozymes in the presence or absence of the herbicide and comparing metabolic degradation of the herbicide in laboratory or greenhouse assays.

Biology, ecology and evolution of herbicide resistance. Many factors influence the evolution of herbicide resistance in weed populations (reviewed in Jasieniuk et al. 1996). To design effective resistance management strategies for the long term, UC and other scientists are conducting basic research on weed biology and on ecological and evolutionary processes in weed populations.

In a few cases, the mechanisms that confer resistance to herbicides have altered the fitness (i.e., survival, growth and/or seed production) of resistant plants, as compared with susceptible plants of the same species in the absence of herbicide treatment. Differential plant fitness among biotypes can affect the rate at which herbicide resistance can spread. For example, if resistant and susceptible plants have equal fitness, the number of resistant plants in the population would not change relative to the number of susceptible plants during periods when the herbicide was not being applied (Jasieniuk et al. 1996). In contrast, if resistant plants are less fit than susceptible plants, the number of resistant plants may decrease during periods when herbicide is not applied. Fitness is usually evaluated by growing resistant and susceptible plants in direct competition with one another, or with the crop of interest, and comparing relative productivity or fecundity.

Similar to efforts for other invasive weeds, insects and disease pathogens, surveys are sometimes used to delineate the extent of population growth or the expansion of new herbicide-resistant weed biotypes. Because there often are a few escaped weeds in herbicide-treated fields, herbicide resistance may not be recognized until the resistant biotype makes up a significant portion of the local population (Vencill et al. 2012). Surveys

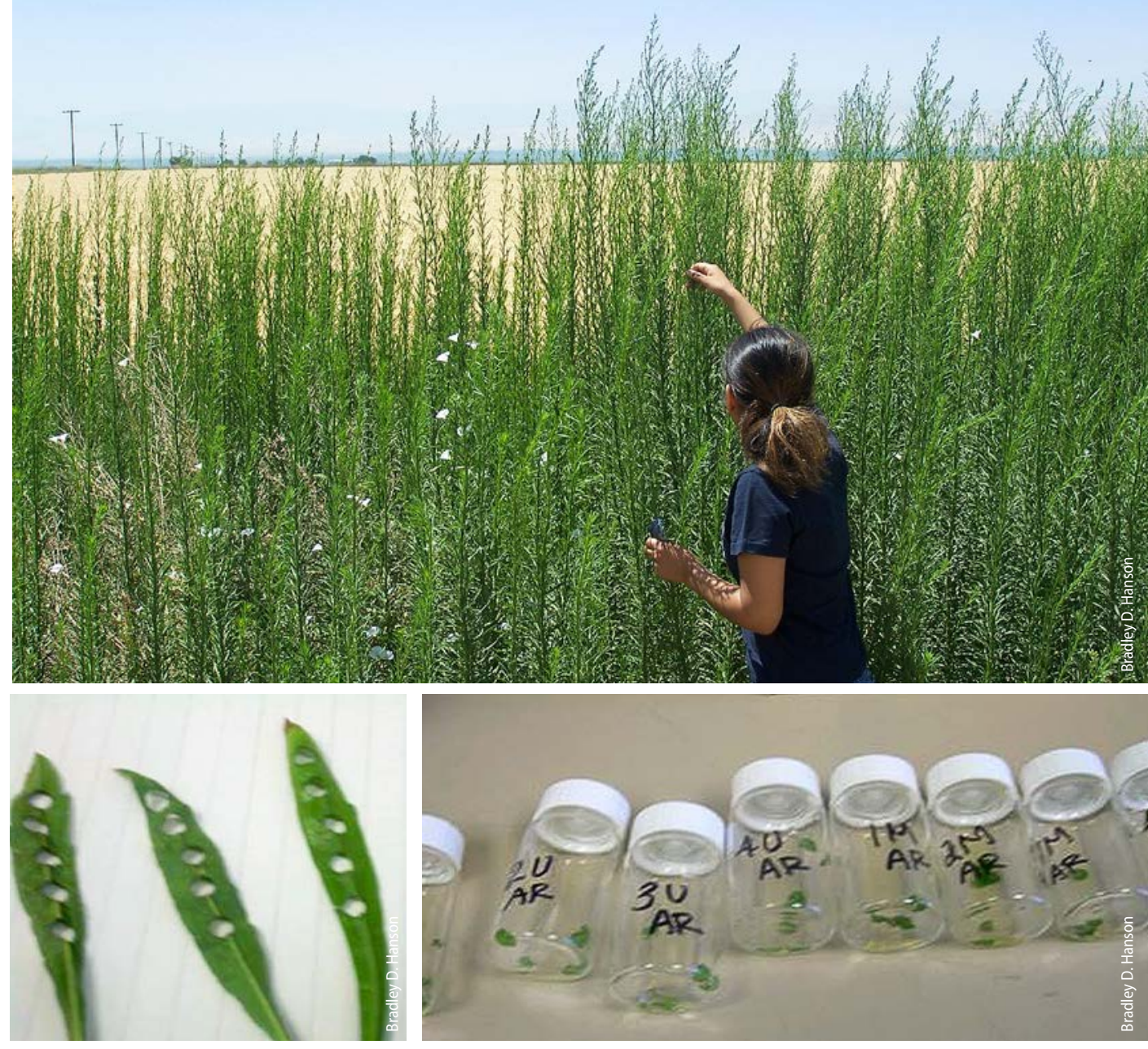

In some cases of herbicide-resistant weeds, enzyme- or tissue-level assays can be used to understand and quantify resistance. Above, a lab assistant collects leaves from suspected glyphosate-resistant horseweed; left, leaf disks from the intact leaves are cut for an in vivo assay; right, disks are incubated overnight in the laboratory in buffer solutions containing various concentrations of glyphosate in order to evaluate activity of the EPSPS enzyme.

can help inform growers of emerging herbicide-resistant weed populations while they are still localized; surveys are also often used to encourage adoption of resistance mitigation measures to minimize economic and environmental impacts.

Further, surveys combined with population genetic research can determine the evolutionary and geographic origins, and routes of spread, of resistance across an agricultural landscape (e.g., Okada et al. 2013; Okada et al. 2014).

\section{Herbicide resistance in California}

Herbicide resistance has been an important management concern in California flooded rice production for several years (Busi et al. 2006). Weeds with resistance to the ALS inhibitors (Group 2), thiocarbamates (Group 8) and ACCase inhibitors (Group 1) are the dominant weed management problems in most of the Sacramento Valley rice production region. In orchards and vineyards, herbicide resistance is a more recent development and is dominated by resistance to the broad-spectrum postemergence herbicide glyphosate. This herbicide is, by far, the most widely used herbicide in the state in perennial crop production systems, as well as in many roadsides, canal banks and residential and industrial areas. Glyphosate-tolerant (Roundup Ready) cotton, alfalfa and corn are becoming widely adopted in the state, which will further increase selection pressure for additional glyphosate-resistant and -tolerant species.

Herbicide resistance in flooded rice. Most California rice is produced in monoculture systems due to impeded soil drainage, which limits rotation to other upland crops (Hill et al. 2006). Rice fields are kept under continuous flood conditions during the growing season, primarily for the control of grass weeds (Strand 2013). Although this system favors sedges and other water-tolerant weeds, selective herbicides such as molinate and bensulfuron provided highly effective weed control for several years. However, in the early 1990s, after repeated use, resistance to the ALS-inhibiting herbicide bensulfuron became widespread among weedy species in rice. By 2000, several additional 
weed biotypes with resistance to ALS inhibitors, thiocarbamates or ACCase inhibitors had evolved and were causing significant weed management, economic and environmental issues in the rice cropping system. UC researchers, extension personnel and industry partners have devoted considerable efforts to understanding and managing herbicide-resistant weeds in rice.

Smallflower umbrella sedge (Cyperus difformis) and California arrowhead (Sagittaria montevidensis) resistance to ALS-inhibiting herbicides was first reported in California rice fields in 1993 following repeated use of bensulfuron (Hill et al. 1994). Field research has shown that California arrowhead is a fairly weak competitor in rice systems (Gibson et al. 2001) and that the ALS-resistant biotypes can be adequately controlled with other registered herbicides. Recently, smallflower umbrella sedge biotypes with multiple resistance to the PSII herbicide propanil and to several ALS-inhibiting herbicides were identified in the Sacramento Valley (Valverde et al. 2014), and research is ongoing to elucidate the mechanisms of resistance and any cross resistance to other rice herbicides.

Eared redstem (Ammannia auriculata) and ricefield bulrush (Schoenoplectus mucronatus) resistance to ALS inhibitor herbicides in rice was reported in 1997. Redstem research has focused on intraand interspecific competition in an effort to develop agronomic solutions to reduce its competition with rice (Caton et al. 1997; Gibson et al. 2003). Studies have shown that California populations of ricefield bulrush are resistant to most registered ALS inhibitors, whereas populations from other regions are resistant only to one chemical family, the sulfonylureas, in the ALS inhibitor group (Busi et al.

2006). Recently, ricefield bulrush biotypes

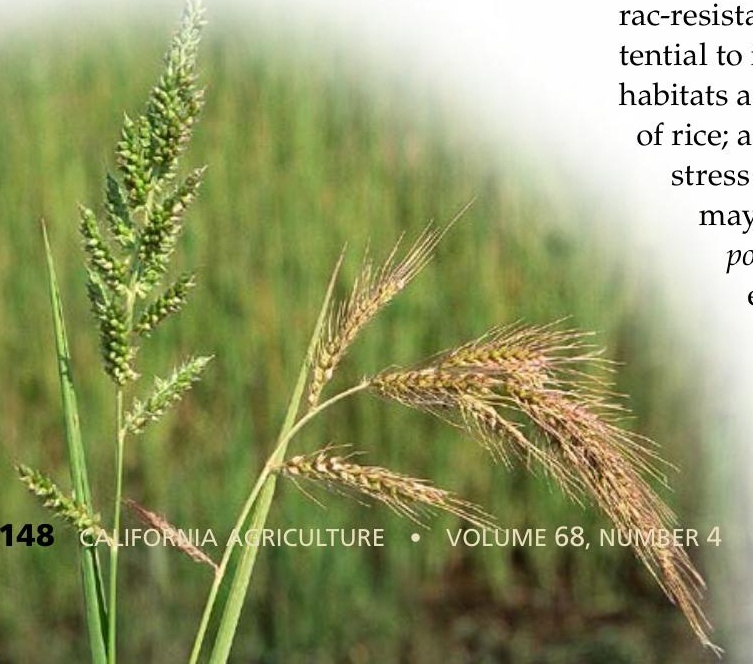

with multiple resistance to propanil and bensulfuron were identified in the Sacramento Valley (Abdallah et al. 2014).

Late watergrass (Echinochloa phyllopogon) populations resistant to ACCase inhibitors, ALS inhibitors and the thiocarbamate herbicides in rice systems were reported in 1998 (Fischer, Ateh et al. 2000; Fischer, Bayer et al. 2000). This resistance to multiple herbicides within an individual plant indicated that using herbicides with different modes of action would be unlikely to provide satisfactory control of the species in the long term. Further complicating the situation in rice, populations of late watergrass and barnyardgrass (Echinochloa crus-galli) with resistance to both ACCase inhibitors and thiocarbamates, and thus exhibiting multiple resistance, were reported in 2000. Later research confirmed that the mechanisms of multiple resistance to several herbicide classes are due to metabolic degradation of these compounds (Yasuor et al. 2008, 2009).

Smooth crabgrass (Digitaria ischaemum) resistance to the synthetic auxin herbicide quinclorac was reported in 2002 Detailed research into the mechanisms of resistance suggested that the cause was an altered sensitivity in the auxin response pathway, leading to ACCase activity, ethylene synthesis and enhanced ability to detoxify cyanide (a byproduct of ethylene biosynthesis) (Abdallah et al. 2006). Although crabgrass is not an important rice weed, quinclorac is used in rice systems for control of other weeds, and resistance to it has been reported in Echinochloa species of rice in California (Yasuor et al. 2011) and from other regions. Most importantly, the observed changes in ethylene synthesis and production of toxic byproducts may also relate to the plant's ability to tolerate abiotic stress. Two implications of this finding include the possibilities that (1) quinclorac-resistant smooth crabgrass has the potential to invade a more diverse range of habitats and become an important weed rice; and (2) adaptation to the abiotic stress of the flooded environments may predispose Echinochloa phyllopogon or other major rice weeds to evolve resistance to quinclorac in the future.

Barnyardgrass (Echinochloa crus-galli).
Herbicide resistance in orchard and vineyard cropping systems. The first herbicide-resistant weed in orchard cropping systems was perennial ryegrass, Lolium perenne (now named Festuca perennis spp. perenne), reported in 1989 (Heap 2013). This ALS inhibitor-resistant biotype was selected on roadsides by the use of sulfometuron and, thus far, has not been a major problem in orchards or vineyards because relatively little of this class of herbicides is used in these crops. However, several ALS inhibitors, including rimsulfuron, penoxsulam, halosulfuron and flazasulfuron, are becoming more widely used in tree and vine crops, and selection pressure for ALS inhibitor resistance may increase in the future.

The first case of glyphosate resistance in California was reported in a population of rigid ryegrass (Lolium rigidum, now Festuca perennis spp. rigidium) in 1998 (Simarmata and Penner 2008). However, most confirmed glyphosateresistant ryegrass populations have been identified as Italian ryegrass (Lolium multiflorum, now Festuca perennis spp. multiflorum) (Sherwood and Jasieniuk 2009). Glyphosate-resistant ryegrasses have become widespread and are a major weed problem in orchards, vineyards and roadsides of Northern California (Jasieniuk et al. 2008). Research indicated that resistance in ryegrass is not due to metabolism of the herbicide and is instead due to an altered EPSPS enzyme (Jasieniuk et al. 2008; Simarmata and Penner 2008). Glyphosate resistance in these areas has been largely driven by decreases in grower use of other herbicides, especially those under increasing regulatory pressure because of pesticide contamination of ground or surface water. The use of glyphosate-based herbicide programs also increased when the patent on Roundup expired in 2000 and low-cost, generic glyphosate herbicides became readily available. Today, glyphosate accounts for over $60 \%$ of all herbicide-treated acreage in California orchard and vineyard systems (DPR 2013).

Glyphosate-resistant horseweed, or mare's tail (Conyza canadensis), was reported in 2005 and is one of the dominant weeds in and around raisin and tree fruit production areas of the San Joaquin Valley, as well as on roadsides and canal banks in the region (Hanson et al. 2009; Hembree and Shrestha 2007; Shrestha, 


\title{
Importance of herbicide resistance in weeds of natural areas
}

\author{
by Joseph M. DiTomaso
}

W

orldwide, the majority of the plant species that are developing herbicide resistance are those that occur as weeds in agricultural environments, on roadsides and in other rights-of-way. In contrast, herbicide resistance is not nearly so common in weeds of natural areas or rangelands. A search of the International Survey of Herbicide Resistant Weeds (weedscience.com) revealed no herbicide-resistant weeds (i.e., invasive nonnative species) listed for terrestrial natural areas anywhere in the world, and only two resistant weeds listed for aquatic areas, both of them in Florida. In pastures, 15 species worldwide have developed resistance, eight of which are considered primarily as agricultural weeds. Only two of those 15 are found in pastures within the United States, and none occurs in any Western state.

The reason more weeds develop herbicide resistance in agricultural and right-of-way systems has to do with factors associated with characteristics of specific weeds, herbicides and weed management practices. For example, high seed production increases the opportunity for genetic variation, and with it the probability that a resistance adaptation will occur. It so happens that all of the major weeds that have developed resistance to herbicides are annuals. In an agricultural system, annual species make up the vast majority of problematic weeds. Annuals can have high seed production, rapid turnover of the seedbank (due to a high percentage of seed germination each year) and, in some cases, several reproductive generations per growing season. This increases the selective pressure for herbicide-resistant biotypes. In natural areas of California, the California Invasive Plant Council (Cal-IPC) lists 214 flowering plants as invasive (cal-ipc.org). Of these, only $27.5 \%$ are annual species; the remainder (and the majority) are either woody species or herbaceous perennials or biennials. Perennial weeds, and particularly those with vegetative reproductive tissues, are less likely than annuals to evolve herbicide resistance.

The choice of herbicide can also increase or decrease the likelihood that weeds will develop herbicide resistance. In most natural areas, herbicides are not used as intensively as in croplands, where it is common to repeat herbicide applications within a single year or over several consecutive years. In addition, fewer herbicides are available for use in natural areas of California, and the most widely used compounds (e.g., 2,4-D, aminopyralid, dicamba, triclopyr or clopyralid) belong to the growth regulator chemical families. Resistance to these herbicides does not develop as commonly as resistance to other herbicide families, despite their having been available and extensively used for a long time. Glyphosate is also commonly used in natural areas, and although glyphosate resistance is on the rise in cropping systems, its development is often associated with repeated applications over multiple years, a strategy not generally used in natural areas.

Weed management practices are often the most important contributing factors leading to the selection of herbicide-resistant biotypes. In general, a land manager's complete and repeated reliance on a single herbicide or mode of action for weed control can greatly enhance the occurrence of herbicide-resistant weeds. This is particularly true when the manager uses no other weed control option, such as mechanical or cultural control practices. For a number of reasons, including economic feasibility and the potential for damage to desirable (nontarget) vegetation, it is uncommon for a land manager to reapply the same herbicide for several consecutive years in a natural area.

Because the evolution of herbicide resistance is typically the result of intensive, persistent selective pressure on a rapidly regenerating weed population (i.e., annual species), the incidence of herbicide-resistant species would be expected to be much higher in a cropping system with limited rotations or in other systems,
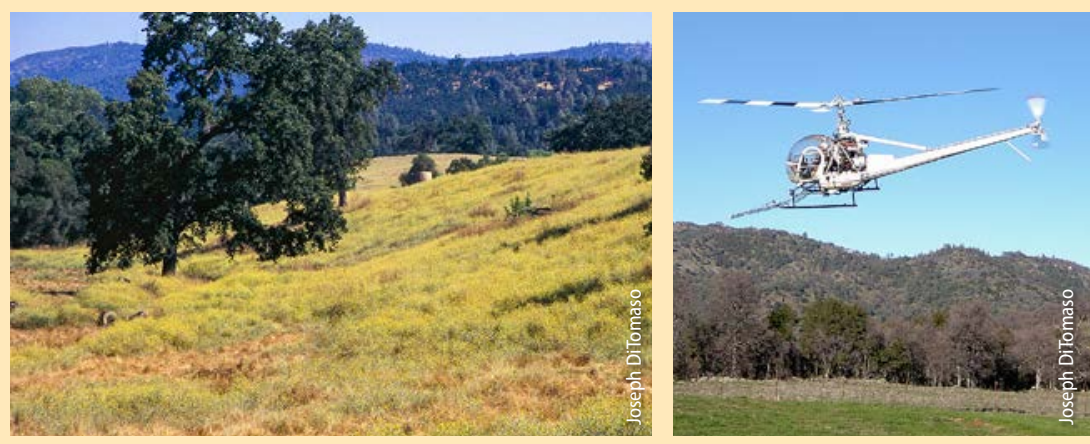

Yellow starthistle (Centaurea solstitialis) infestation, left; aerial spraying to control yellow starthistle near Sierra Foothill Research and Extension Center, right.

such as rights-of-way, that are continuously managed with herbicides. In many natural areas, the effort to manage invasive plants can involve several different control strategies besides, or instead of, herbicide application. These can include mechanical means such as mowing, cultural methods including grazing management or prescribed burning and, when available, biological control agents. Furthermore, even when herbicides are used, they are rarely applied repeatedly over a long period of time. The total area of noncropped lands treated with herbicides is far smaller than the total acreage of agricultural land treated with herbicides. It is hardly surprising, then, that the incidence of herbicide resistance in natural areas and rangelands is low - in fact, it is not even reported at present in California.

Regardless of the vegetative environment, whether natural or agricultural, prevention of herbicide resistance and management of established resistant weed populations could be accomplished more effectively if we put a greater reliance on integrated weed management approaches. Although the likelihood that resistance will develop in natural areas is already low, management strategies that employ rotation of herbicides with different modes of action, the use of competitive species in restoration programs, and a combination of mechanical, biological and cultural control options in an integrated management program will further reduce the selective pressure on invasive plant populations and with it the potential that weeds will develop herbicide resistance.

J.M. DiTomaso is UC Cooperative Extension Specialist, Department of Plant Sciences, UC Davis. 
Hembree, Wright 2008; Shrestha et al. 2010). The level of glyphosate resistance in horseweed is relatively low, and resistant plants are usually injured to some degree following glyphosate applications, which suggests that resistance is not due to an altered target enzyme. Genetic comparisons of horseweed accessions from around the state suggest that there have been multiple, independent origins of resistance in this species, rather than the spread of resistance from a single-source population (Okada et al. 2013).

Hairy fleabane (Conyza bonariensis) populations resistant to glyphosate were reported in 2007 (Shrestha, Hanson,
Hembree 2008). Glyphosate resistance in hairy fleabane appears to be similar to resistance in horseweed in that (1) selection has occurred in response to similar management strategies in perennial crops and surrounding areas (Hembree and Shrestha 2007); (2) multiple origins of resistance are suspected (Okada et el. 2014); and (3) growth stage and environmental conditions affect the level of resistance (Moretti, Hanson et al. 2013; Shrestha et al. 2007). The discovery by Moretti, Hanson et al. (2013) of hairy fleabane resistant to both glyphosate and paraquat raises questions about whether a common physiological mechanism is helping to confer resistance to these dissimilar herbicides, and research is ongoing to elucidate these factors.

Junglerice (Echinochloa colona) resistant to glyphosate was first identified in 2008 in a Roundup Ready corn field in the Sacramento Valley (Alarcon-Reverte et al. 2013); since then, glyphosate-resistant junglerice has become widespread in orchards and field crops throughout California (Moretti, Garcia et al. 2013). Resistance appears to be due to mutations in the EPSPS target site (Alarcon-Reverte et al. 2013), although some populations also appear to have enhanced EPSPS activity (A.J. Fischer, unpublished data).

\section{Herbicide-resistant weeds unlikely in vegetable crops}

\section{by Steve Fennimore, Richard Smith and Michelle Le Strange}

W eed management systems in California vegetable crops can be described as robust, complex, multitactic and integrated. Vegetable herbicides generally make up just one component in a multicomponent weed management system. With California's seasonally dry weather and growers' ability to control soil moisture by means of irrigation scheduling, it becomes possible for the grower to apply effective cultural and physical control practices, such as preparation of stale seedbeds and inter-row cultivation. Redundancy is designed into the weed management system to minimize weed emergence in the crop. The key tools that make up an integrated vegetable weed management system are field selection, sanitation, crop rotation, land preparation, stale seedbeds, herbicides and physical weed control (UC IPM 2009). Growers who carefully apply these practices are able to manage weeds effectively and reduce the presence of weed seeds in the soil seedbank.

Field selection. Farmers often grow vegetable crops on fields that have low weed pressure so their weed control operations can be more efficient and economical. They use translocated herbicides during fallow periods to control troublesome perennial weeds like field bindweed.

Sanitation. Growers often keep vegetable fields and the surrounding areas as weed-free as possible to keep the weeds from going to seed. Some operations that utilize a "zero weed seed" philosophy have successfully reduced weed pressure in subsequent vegetable crops by eliminating weed seed inputs to the soil seedbank. Other measures such as cleaning all field equipment when moving it from a weedy field or into a clean field are also employed.

Rotation. By growing vegetable crops in rotation with crops that normally have more intensive weed control programs, growers can help keep a field clean of weeds. Because field conditions are constantly changing under a rotation system, no one weed species is likely to become dominant.

Land preparation. Direct-seeded vegetable crops require wellprepared seedbeds free of large clods to facilitate precision planting and allow rapid and uniform emergence of vegetable seedlings. A uniform seeding depth is critical to uniform crop emergence and improved tolerance to herbicides. Mechanical cultivation is facilitated with smooth seedbeds and good tilth, which allows the cultivation equipment to remove weeds that are close to the crop row. Increasingly, growers are using precision guidance systems to improve the speed and accuracy of cultivation.

Preirrigation and use of a stale seedbed. Preirrigation before final seedbed preparation is a common practice, as it stimulates a weed flush a few days after watering. As soon as the weeds have emerged and the field is dry enough to enter, the grower uses shallow cultivation, flaming or a nonselective herbicide to remove the new weeds. Research has shown this technique to provide $15 \%$ to $50 \%$ control of weeds in crops like lettuce (Shem Tov et al. 2006). The combination of stale seedbed technique and both herbicides and cultivation often results in good weed control.

Herbicides. One category of herbicide used in vegetable crops is fumigants, such as metam potassium, which is applied 14 to 21 days before planting to kill weed seeds and germinating seedlings. After planting, soil-active herbicides like pronamide (used in artichokes and head lettuce) and S-metolachlor and trifluralin (used in tomatoes and peppers) are applied to provide preemergence control of weeds. Postemergence herbicides are utilized in some crops; examples include clethodim, used to control emerged grass weeds in many broadleaf vegetable crops, and oxyfluorfen and bromoxynil, used to control broadleaf weeds. Many vegetable herbicides were developed in the 1960s and 1970s and include products like DCPA (used in broccoli and onion), napropamide (used in tomatoes and peppers) and linuron (used in asparagus and celery). Given the complexity of the vegetable weed control program and the extensive use of cultivation and hand-weeding, the selective pressure on weeds from vegetable herbicides is very light, despite their decades of use.

Physical weed control. Vegetable growers make extensive use of physical weed control. One example is inter-row cultivation or shallow cultivation between the crop rows to control weeds. Interrow cultivation is a very old but effective method that buries, cuts or uproots weeds. Hand-weeding by workers with hoes is the last 
Target-site mutations appear to be the most frequent mechanism among the accessions so far collected in California; however, additional research is ongoing to determine whether the same is true with populations selected in orchards and in other regions of the Central Valley.

Several other common weeds in orchards and vineyards, including Palmer amaranth (Amaranthus palmeri), threespike goosegrass (Eleusine tristachya) and witchgrass (Panicum capillare), are suspected to have evolved resistance to glyphosate; preliminary research trials by UC researchers and California State University, Fresno, collaborators have been initiated to verify and characterize the putative resistant populations.

\section{California herbicide resistance research: Locally applied research and exten- sion with national and international implications}

Since the discovery of herbicideresistant weed biotypes in California, UC research and Cooperative Extension personnel, as well as university and nonuniversity cooperators and students, have conducted locally relevant weed management research in the state. Research and extension efforts have included alternative chemical management techniques using various postemergence and preemergence herbicides along with mechanical control measures in an integrated approach. Applied research integrating agronomy, weed control, spray application technology and water management have been useful to regulatory agencies (e.g., California Department of Pesticide Regulation and California Environmental Protection Agency) and have had positive impacts on water and air quality, wildlife habitat and water use (Pittelkow et al. 2012).

Information on the underlying mechanisms and genetic basis of resistance provides useful information to California line of defense against weeds in vegetable crops. Among the hoeing crew, manual dexterity and good depth perception allow the workers to carefully remove weeds from the vegetable crop in the row and near the crop plant. Hand-weeding is expensive and can cost $\$ 300$ or more per acre in organic vegetable plantings and highdensity plantings (e.g., spinach and baby lettuces) — sometimes a lot more.

Integrated weed management in lettuce. In a typical lettuce weed control program, the crop is grown on a field with a light weed population, so one tool growers use is field selection. Sometimes the soil is fumigated with metam potassium before planting to control weeds and soilborne diseases, but most lettuce is grown on nonfumigated land. Prior to planting, the soil is irrigated to stimulate weed emergence and then shallow-tilled to kill weeds and form a smooth seedbed for planting. At time of seeding, preemergence herbicides such as pronamide or bensulide are applied, to be activated with the initial sprinkler irrigation. About 4 weeks after emergence, the lettuce is hand-thinned and weeded by a hoeing crew to its final stand. Inter-row cultivation in furrows and on bed tops is conducted one or more times, also removing weeds. Finally, about 6 weeks after lettuce emergence, the field is hand-weeded to remove any remaining weeds. After harvest, the field is quickly tilled under, killing any remaining weeds before the field is rotated to another crop.

Integrated weed management in tomatoes. Virtually all California tomatoes are transplanted, and $75 \%$ are grown using subsurface drip irrigation buried 8 to 10 inches deep. Fields with low weed populations, especially those free of field bindweed and dodder, are most often sought for tomato production. Beds are preirrigated to germinate weeds, then cultivated and shaped prior to planting. Typically only two herbicide applications are made: one just prior to planting or at planting, and the other at layby. Herbicides such as halosulfuron, pendimethalin, rimsulfuron, S-metolachlor, sulfentrazone and trifluralin are used, depending upon the site and weed spectrum. Just prior to layby application, beds and furrows are mechanically cultivated.

These practices significantly reduce weed emergence and competition against the young tomato crop. Hoeing crews may handweed once or twice before or after layby, depending on weed populations. Adding to the cost for growers who practice "zero weed seed tolerance" is the physical removal of troublesome weeds such as flowering nightshades and dodder to prevent seeding and further field contamination. The harvest operation undercuts all plants growing on the bed top, and after harvest the field is quickly tilled under, killing any remaining weeds before the field is rotated to another crop.

The lettuce and tomato weed management systems are intensive and redundant, made up of many operations conducted in sequence with the aim of minimizing weed emergence. In practice, these weed management systems are not always as flawless as the above descriptions might suggest. Crops like broccoli and cauliflower are grown during winter months, when extended rain and wet field conditions prevent cultivation and hand-weeding. Other complications are high-density plantings such as those used for spinach, which limit the grower's ability to cultivate.

Overall, the chances are low that weeds will develop herbicide resistance in a vegetable crop planting. Technology is evolving that will allow intelligent robotic cultivators to remove weeds from the intra-row space without the use of herbicides, so there is reason for optimism that the development of herbicide-resistant weeds in California vegetable fields will remain low for the foreseeable future.

S. Fennimore is UC Cooperative Extension (UCCE) Specialist, Department of Plant Sciences, UC Davis; R. Smith is UCCE Farm Advisor, Monterey County; and M. Le Strange is UCCE Farm Advisor Emeritus, Tulare County.

\section{References}

Shem-Tov S, Fennimore SA, Lanini WT. 2006. Weed management in lettuce (Lactuca sativa) with pre-plant irrigation. Weed Technol 20:1058-65.

UC IPM. 2009. Integrated weed management. In: Spinach: UC IPM Pest Management Guidelines. UC ANR Pub 3467. Oakland, CA. www.ipm.ucdavis.edu/PMG/ r732700111.html. 
weed managers in the longer term. This information is broadly applicable to the biology, physiology, evolution and control of weeds in other crops and regions at the local, national and international level. Although this paper has focused on the efforts of UC weed scientists and collaborators, the basic and applied scientific information developed in California supports similar research being conducted in other regions of the country and world.

Like many other areas encompassed by the Endemic and Invasive Pests and Diseases Strategic Initiative, solutions to herbicide resistance are not simple and are affected by many biological, economic, regulatory and social factors. The diverse network of weed scientists and collaborators in a land-grant university system is well positioned to address these complex issues and respond to stakeholder concerns through applied and basic research, extension and outreach to affected agricultural industries, and education of future scientists and leaders. Ultimately, the goal of weed science research is to help growers maintain agricultural productivity and economic stability while increasing environmental sustainability. CA
B.D. Hanson is UC Cooperative Extension (UCCE) Specialist, Department of Plant Sciences, UC Davis, S. Wright is UCCE Farm Advisor, Tulare County; L.M. Sosnoskie is Project Scientist, Department of Plant Sciences, UC Davis; A.J. Fischer is Professor, Department of Plant Sciences, UC Davis; M. Jasieniuk is Professor, Department of Plant Sciences, UC Davis; J.A. Roncoroni is UCCE Farm Advisor, Napa County; K.J. Hembree is UCCE Farm Advisor, Fresno County; S. Orloff is UCCE Farm Advisor and County Director, Siskiyou County; A. Shrestha is Professor, Department of Plant Science, California State University, Fresno; K. Al-Khatib is

Director, UC Statewide Integrated Pest Management Program.

\section{References}

Abdallah I, Fischer AJ, Elmore CL, et al. 2006. Mechanism of resistance to quinclorac in smooth crabgrass (Digitaria ischaemum). Pestic Biochem Physiol 84:38-48.

Abdallah IS, Garcia A, Fischer AJ. 2014. Rice field bulrush (Schoenoplectus mucronatus (L.) Palla) evolved multiple resistances to propanil and bensulfuron herbicides. J Biol Chem Res 31:788-99.

Alarcon-Reverte R, Garcia A, Urzua J, Fisher AJ. 2013. Resistance to glyphosate in junglerice (Echinochloa colona) from California. Weed Sci 61:48-54.

Busi R, Vidotto F, Fischer AJ, et al. 2006. Patterns of resistance to ALS herbicides in smallflower umbrella sedge (Cyperus difformis) and ricefield bulrush (Schoenoplectus mucronatus). Weed Technol 20:1004-14.

Caton BP, Foin TC, Hill JE. 1997. Mechanisms of competition for light between rice (Oryza sativa) and redstem (Ammannia spp.). Weed Sci 45:269-75.

[DPR] California Department of Pesticide Regulation. 2013. Pesticide use reporting. www.cdpr.ca.gov/docs/ pur/pur11 rep/11_pur.htm (accessed on March 1, 2013) Culpepper SA. 2006. Glyphosate-induced weed shifts. Weed Technol 20:277-81.

Délye C. 2013. Unraveling the genetics bases of nontarget-site-based resistance (NTSR) to herbicides: A majo challenge for weed science in the forthcoming decade. Pest Manag Sci 69:176-87.

Délye C, Jasieniuk M, Le Corre V. 2013. Deciphering the evolution of herbicide resistance in weeds. Trends Genet 29:649-58.

Fischer AJ, Ateh CM, Bayer DE, Hill JE. 2000. Herbicideresistant Echinochloa oryzoides and E. phyllopogon in California Oryza sativa fields. Weed Sci 48:225-30.

Fischer AJ, Bayer DE, Carriere MD, et al. 2000. Mechanisms of resistance to bispyribac-sodium in an Echino chloa phyllopogon accession. Pestic Biochem Physiol 68:156-65.

Gaines TA, Shaner DL, Ward SM, et al. 2011. Mechanism of resistance of evolved glyphosate-resistant Palmer amaranth (Amaranthus palmeri). J Ag Food Chem 59:5886-9. Gibson KD, Fischer AJ, Foin TC. 2001. Shading and the growth and photosynthetic responses of Ammannia coccinnea. Weed Res 41:59-67.

Gibson KD, Fischer AJ, Foin TC, Hill JE. 2003. Crop traits related to weed suppression in water-seeded rice (Oryza sativa $\mathrm{L})$. Weed Sci 51:87-93.

Hanson B, Fisher A, Shrestha A, et al. 2013. Selection Pressure, Shifting Populations, and Herbicide Resistance and Tolerance. UC ANR Pub 8493. Oakland, CA. 6 p.

Hanson BD, Shrestha A, Shaner DL. 2009. Distribution of glyphosate-resistant horseweed (Conyza canadensis) and relationship to cropping systems in the Central Valley of California. Weed Sci 57:48-53.
Heap I. 2013. The International Survey of Herbicide Resistant Weeds. www.weedscience.com (accessed August 30, 2013)

Hembree K, Shrestha A. 2007. Control of glyphosateresistant marestail and hairy fleabane in orchards and vineyards. California Weed Science Society Proc 59:113-7. Hill JE, Smith RJ, Bayer DE. 1994. Rice weed control: Current technology and emerging issues in temperate rice. Aust J Exp Agr 34:1020-9.

Hill JE, Williams JF, Mutters RG, Greer CA. 2006. The California rice cropping system: Agronomic and natural resource issues for long-term sustainability. Paddy Water Environ 4:13-9.

Holt JS, Stemler AJ, Radosevich SR. 1981. Differential light responses of photosynthesis by triazine-resistant and triazine-susceptible Senecio vulgaris biotypes. Plant Physiol 67:744-8.

Jasieniuk M, Ahmad R, Sherwood AM, et al. 2008 Glyphosate-resistant Italian ryegrass (Lolium multiflorum) in California: Distribution, response to glyphosate, and molecular evidence for an altered target enzyme. Weed Sci 56:496-502.

Jasieniuk M, Brule-Babel AL, Morrison IN. 1996. The evolu tion and genetics of herbicide resistance in weeds. Weed Sci 44:176-93.

Maxwell BD, Roush ML, Radosevich SR. 1990. Predicting the evolution and dynamics of herbicide resistance in weed populations. Weed Technol 4:2-13.

Moretti ML, Garcia AM, Fischer AJ, Hanson BD. 2013. Distribution of glyphosate-resistant junglerice (Echinochloa colona) in perennial crops of the Central Valley of California. Proc Western Soc Weed Sci 66:19.

Moretti ML, Hanson BD, Hembree KJ, Shrestha A. 2013. Glyphosate resistance is more variable than paraquat resistance in a multiple-resistant hairy fleabane (Conyza bonariensis) population. Weed Sci 61:396-402.

Okada M, Hanson BD, Hembree KJ, et al. 2013. Evolution and spread of glyphosate resistance in Conyza canaden sis in California. Evol Appl 6:761-77.

Okada M, Hanson BD, Hembree KJ, et al. 2014. Evolution and spread of glyphosate resistance in Conyza bonariensis in California and a comparison with closely related C. canadensis. Weed Res (in press)

Orloff SB, Putnam DH, Canevari M, Lanini WT. 2009. Avoiding Weed Shifts and Weed Resistance in Roundup Ready Alfalfa Systems. UC ANR Pub 8362. Oakland, CA.

Pimentel D, Zuniga R, Morrison D. 2005. Update on the environmental and economic costs associated with alien-invasive weeds in the United States. Ecol Econ 52:273-88.
Pittelkow CM, Fischer AJ, Moechnig MJ, et al. 2012. Agronomic productivity and nitrogen requirements of alternative tillage and crop establishment systems for improved weed control in direct-seeded rice. Field Crop Res 130:128-37.

Prather TS, DiTomaso JM, Holt JS. 2000. Herbicide resistance: Definitions and management strategies. UC ANR Pub 8012. Oakland, CA. 12 p.

Sherwood AM, Jasieniuk M. 2009. Molecular identification of weedy glyphosate-resistant Lolium (Poaceae) in California. Weed Res 49:354-64.

Shrestha A, Hanson BD, Fidelibus MW, Alcorta M. 2010 Growth, phenology, and intraspecific competition between glyphosate-resistant and glyphosate-susceptible horseweeds (Conyza canadensis) in the San Joaquin Valley of California. Weed Sci 58:147-53.

Shrestha A, Hanson BD, Hembree KJ. 2008. Glyphosateresistant hairy fleabane documented in the Central Valley. Calif Agr 62:116-9.

Shrestha A, Hembree KJ, Va N. 2007. Growth stage influences level of resistance in glyphosate-resistant horseweed. Calif Agr 61:67-70.

Shrestha A, Hembree K, Wright S. 2008. Biology and management of horseweed and hairy fleabane in California. UC ANR Pub 8314. Oakland, CA. p 9.

Simarmata M, Penner D. 2008. The basis for glyphosate resistance in rigid ryegrass (Lolium rigidum) from California. Weed Sci 56:181-8

Strand L. 2013. Integrated Pest Management for Rice (3rd ed.). UC ANR Pub 3280. Oakland, CA. 98 p.

Valverde BE, Boddy LG, Pedroso RM, et al. 2014. Cyperus difformis evolves resistance to propanil. Crop Prot 62:16-22.

Vencill WK, Nichols RL, Webster TM, et al. 2012. Herbicide resistance: Toward an understanding of resistance development and the impact of herbicide-resistant crops. Weed Sci 60 (Special Issue):2-30.

Yasuor H, Milan M, Eckert JW, Fischer AJ. 2011. Quinclorac resistance: A concerted hormonal and enzymatic effort in Echinochloa phyllopogon. Pest Manag Sci 68:108-15.

Yasuor H, Osuna MD, Ortiz A, et al. 2009. Mechanisms of resistance to penoxsulam in late watergrass (Echinochloa phyllopogon). J Agr Food Chem 57:3653-60.

Yasuor H, TenBrook PL, Tjeerdema JS, Fischer AJ. 2008. Response to clomazone and 5-ketochlomazone by Echinochloa phyllopogon resistant to multiple herbicides in Californian rice fields. Pest Manag Sci 10:1031-9.

Yuan JS, Tranel PJ, Stewart Jr CN. 2007. Non-target-site herbicide resistance: A family business. Trends Plant Sci 12:6-13. 